\title{
Could the connectedness of primary health care workers involved in social networks affect their job burnout? A cross-sectional study in six counties, Central China
}

Yiqing Mao ${ }^{1,2}$, Hang Fu ${ }^{3}$, Zhanchun Feng ${ }^{1,2^{*}}$ (D) Da Feng ${ }^{4}$, Xiaoyu Chen ${ }^{1,2}$, Jian Yang ${ }^{1,2}$ and Yuanqing Li $i^{1,2}$

\begin{abstract}
Background: This study aimed to reveal the effects of the connectedness of primary health care (PHC) workers in social networks on their job burnout.

Methods: Cross-sectional survey data of rural PHC workers in China were analyzed. A total of 663 respondents were enrolled. Chi-square and cumulative logistic regression were used to determine the effects of the connectedness of PHC workers in social networks on their job burnout.

Results: PHC workers in rural China had high levels of emotional exhaustion (24.1\%), depersonalization (15.7\%), and lack of personal accomplishment (34.7\%). More than half of the participants were in the middle connectedness level in terms of their advisory (70.4\%) and friendship (70.3\%) networks. The degree of emotional exhaustion seemed to increase when participants had a low connectedness in their friendship networks $(\beta=0.769,95 \% \mathrm{Cl}=$ $0.080-1.458, P=0.029$ ). Respondents with the middle level of connectedness in advisory networks had higher levels of depersonalization $(\beta=0.739,95 \% C l=0.130-1.348, P=0.017)$ and lack of personal accomplishment $(\beta=0.583$, $95 \% \mathrm{Cl}=0.111-1.055, P=0.015)$ than those with the high degree of connectedness in advisory networks.

Conclusions: The connectedness of PHC workers in social networks influenced their job burnout. Thus, organizations should establish an informal communication platform and information feedback mechanism, promote and manage friendship networks, and help PHC workers overcome emotional exhaustion. Managers should also encourage individuals with a high level of connectedness in advisory networks play the role of "opinion leader" so that they can help others mitigate burnout.
\end{abstract}

Keywords: Primary health care workers, Connectedness, Social networks, Job burnout

\footnotetext{
* Correspondence: zcfeng@hust.edu.cn

${ }^{1}$ School of Medicine and Health Management, Tongji Medical College,

Huazhong University of Science and Technology, Wuhan 430030, Hubei, China

${ }^{2}$ Research center for Rural Health Services, Hubei Province Key Research Institute of Humanities and Social Sciences, Wuhan 430030, Hubei, China Full list of author information is available at the end of the article
}

(c) The Author(s). 2020 Open Access This article is licensed under a Creative Commons Attribution 4.0 International License, which permits use, sharing, adaptation, distribution and reproduction in any medium or format, as long as you give appropriate credit to the original author(s) and the source, provide a link to the Creative Commons licence, and indicate if changes were made. The images or other third party material in this article are included in the article's Creative Commons licence, unless indicated otherwise in a credit line to the material. If material is not included in the article's Creative Commons licence and your intended use is not permitted by statutory regulation or exceeds the permitted use, you will need to obtain permission directly from the copyright holder. To view a copy of this licence, visit http://creativecommons.org/licenses/by/4.0/ The Creative Commons Public Domain Dedication waiver (http://creativecommons.org/publicdomain/zero/1.0/) applies to the data made available in this article, unless otherwise stated in a credit line to the data. 


\section{Background}

Given the theme of the 72nd World Health Assembly ("From primary health care (PHC) to universal health coverage and sustainable development goal"), PHC has played an important role in implementing universal health coverage and achieving a healthy strategy in China. Healthcare workers are the first resource for PHC services [1]. However, the shortage of PHC workers is a global problem, and such concern is especially serious in rural areas [2]. In China, only 1.8 physicians per 1000 people were available in rural areas in 2018, a figure equivalent to only $45 \%$ of their counterparts for urban areas [3]. The shortage of personnel greatly affects the quality of PHC services. In addition to income level and career development prospects [4], job burnout is an important factor that affects the loss and shortage of rural PHC workers. Rural PHC workers commonly face job burnout, a situation that may contribute to the high staff turnover [5]. Accordingly, job burnout can increase the shortage of rural PHC workers. Burnout can also affect an individual's physical and mental health and cause lower personal performance [6]. All of these can lead to the high instability of a PHC network.

Job burnout is a kind of sub-health state of chronic stress that is associated with limited resources, abilities, energies, and interests in long-term work. Furthermore, it involves emotional exhaustion, depersonalization, and lack of personal accomplishment [7]. Burnout is a global occupational hazard among PHC workers [5]. PHC workers experience burnout due to relatively less work resource, lower wages, and worse career development opportunities compared with health care workers in general organizations [8]. Previous studies also revealed that individual factors (such as age, gender, educational background, work experiences [years], monthly income, and daily work hours) can influence the job burnout of PHC workers [9-11]. Moreover, job burnout of different professional PHC workers vary. Xu reported that doctors had higher level of burnout than nurses, pharmacists, and other technicians of the PHC network [8].

In China, the unique health care service model in rural areas may lead to other determinants of job burnout. The service model of rural PHC workers had changed greatly, from providing services independently to working in teams since the implementation of new health care reform in 2009. Presently, most rural PHC workers who provide services take the team work for residents, such as establishing family physician groups [12]. The team work model generates more connections with others in the organization in comparison with independent working methods. Therefore, an interpersonal relationship in the team work mode can be more critical when working in a cooperative way, and such a relationship plays an important role in causing the job burnout of PHC workers. At present, some research have revealed the relationship between interpersonal relationship and job burnout. As Hayes B's a review, the relationship of nurses with physicians had the highest negative influence on job burnout [13]. Sun JW confirmed that interpersonal relationships and management issues most strongly predicted participants' burnout [14]. Furthermore, many studies verified the key value of connections with colleagues to job burnout, such as those related to interpersonal justice [15], interpersonal conflicts [16], and group noncooperation [17]. Therefore, relationships with colleagues play a central role in helping individuals produce high performance [18] and in decreasing the level of job burnout in organizations [19]. However, prior investigations only focused on the qualities of relationships, such as closeness and intimacy [20] and did not examine the position (influence) of individuals in relational structures, that is, they overlooked the connectedness of workers involved in social networks.

Sociologists claimed that an individual's interpersonal relationships can behave as if in a social network, and the extent to which an individual's influence in the network is his "connectedness" as measured through the degree centrality index using social network analysis (SNA). Individuals with a high level of connectedness are in the central location in their social networks and are more influential in organizations [21]. According to different occupational relationships, two kinds of social networks exist in organizations-advisory and friendship networks [22]. Advisory networks are formed according to the need for job exchanges, whereas friendship networks arise from personal emotion. In terms of PHC workers, numerous studies proved that PHC workers' behaviors were affected by the connectedness of their social networks [23]. Job burnout can also be seen as a behavior. Hence, we hypothesize that the connectedness of PHC workers involved in social networks can affect their job burnout. The present study attempts to identify the connectedness of PHC workers in rural China using SNA and explore the effects on their job burnout. Scientific evidence can help address job burnout effectively and improve the qualities of $\mathrm{PHC}$ in rural China.

\section{Methods}

\section{Study design and sample}

A cross-sectional survey study was conducted from December 2016 to March 2017. The convenience sampling method was used in this research, particularly the data requirements according to SNA. First, sample areas were selected on the basis of the cooperation foundation that was already established with the research group. Six counties were selected, namely, Zhijiang, Zaoyang, and Suizhou in Hubei Province, and Tanghe, Xixian, and 
Huaibin in Henan Province. Six counties were located in central China. Second, three to five township hospitals were selected from each of the sample areas according to their performance ranking in the previous year: "high, " "middle," and "low" ranks. A total of 21 township hospitals were selected as sample hospitals. Third, sample populations were determined through the preliminary screening of the rosters of all personnel in each sample hospital and by considering all the people involved in the PHC services, including clinicians, nurses, public health workers, and village doctors. Each sample hospital had 30-35 respondents (average number: 33). A total of 663 PHC workers completed the survey. The response rate was $96.0 \%(663 / 690)$.

All participants were convened to complete the questionnaires. Questions, response choices, and academic investigations were explained to them before they filled in the questionnaires. The names of sample populations were replaced by numbers and were included in the lists distributed to each participant in order to investigate the social network of workers. Communicating with each other while filling out the questionnaires was forbidden to ensure the quality of the network data. The Cronbach's alpha coefficient and average variance extracted (AVE) values were 0.849 and 0.552 , respectively. The reliability and validity of the questionnaire were deemed acceptable because the Cronbach's alpha coefficient and AVE values exceeded 0.7 and 0.5 , respectively.

\section{Data measures}

The dependent variable was the level of job burnout, which involved three dimensions: emotional exhaustion, depersonalization, and lack of personal accomplishment [24]. This was measured by the Maslach Burnout Inventory consisting of 22 items. Each item was scored from 0 to 6 on the self-reported frequency of the feeling addressed by each item. The emotional exhaustion domain consisted of nine items for a total score range of $0-54$. Scores below $19,19-26$, and above 26 respectively indicated low, middle, and high levels of emotional exhaustion. The depersonalization domain consisted of five items for a total score range of $0-30$. Scores below 6, 6-9, and above 9 indicated low, middle, and high levels of depersonalization, respectively. The personal accomplishment domain consisted of eight items for a total score range of $0-48$. Score below 34, 34-39, and above 39 respectively indicated high, middle, and low levels of lack of personal accomplishment.

The independent variable was the connectedness of PHC workers in their advisory and friendship networks. The following questions measured the connectedness of advisory networks [25]: (1) Which colleagues will you consult when you encounter difficulties in your work? (2) Which colleagues will take the initiative to guide you when you encounter difficulties in your work? To measure the connectedness of friendship networks, the following queries were investigated: (1) Who are your close friends in private in addition to formal colleague relationships? (2) Which colleagues can help you keep secrets? Connectedness in networks was then measured using the degree centrality index of the SNA. The connectedness in the workers' advisory and friendship networks was divided into high, middle, and low levels based on the average scores of degree centralities (advisory networks: $9.57 \pm 11.40$, friendship networks:7.95 \pm 8.16). Individuals with a high level of connectedness are those who are in the central location in their social networks and are more influential in their organizations. Individuals with low connectedness levels include those who are at the edge of their social networks and are less influential in their organizations. Individuals with a middle level of connectedness are between the central and edge locations in their social networks and are commonly influential in their organizations. Degree centrality index was calculated using Formula (1). Standardizing the values for comparing degree centrality (Formula [2]) is necessary.

$$
\begin{aligned}
& C_{D}\left(n_{i}\right)=d\left(n_{i}\right)=\sum_{j} X_{i j}, \\
& C_{D}^{\prime}\left(n_{i}\right)=d\left(n_{i}\right) /(g-1) .
\end{aligned}
$$

$X_{i j}=$ relationship between $I$ and $J$. If a relationship exists, then $X_{i j}=1$, Otherwise, $X_{i j}=0$.

$g=$ the total number of people in the network.

The control variables comprised factors that might influence the results of connectedness acting on job burnout, including (1) types of work, (2) age, (3) gender, (4) educational background, (5) work experience (in years), (6) monthly income, and (7) daily work hours. The questionnaire used in this study is provided as Additional File 1.

\section{Statistical analysis}

All data were independently double-entered and validated using EpiData. All statistical analyses were performed with SPSS. The degree centrality index was calculated with UCINET. All variables were presented as frequency distribution and percentage. The chi-square test was employed to investigate the corresponding associations of job burnout with the independent and control variables. Only variables with statistically significant differences were included in the cumulative logistic regression model. Values with $P<0.05$ (two tailed) were considered statistically significant. 
Table 1 Socio-demographic, connectedness in networks and job burnout level of PHC workers in rural China

\begin{tabular}{|c|c|c|c|}
\hline Characteristics & & Frequency & Percentage $\%$ \\
\hline \multirow[t]{4}{*}{ Types of work } & Doctors & 131 & 19.8 \\
\hline & Nurses & 105 & 15.8 \\
\hline & Public health workers & 102 & 15,4 \\
\hline & Village doctors & 325 & 49.0 \\
\hline \multirow[t]{2}{*}{ Gender } & Male & 368 & 55.5 \\
\hline & Female & 295 & 44.5 \\
\hline \multirow[t]{4}{*}{ Age } & $\leq 35$ & 182 & 27.5 \\
\hline & $36-45$ & 252 & 38.0 \\
\hline & $46-55$ & 157 & 23.7 \\
\hline & $\geq 56$ & 72 & 10.9 \\
\hline \multirow[t]{3}{*}{ Educational Background } & Undergraduate Degree and Above & 124 & 18.7 \\
\hline & College Degree & 322 & 48.6 \\
\hline & High School and Below & 217 & 32.7 \\
\hline \multirow[t]{3}{*}{ Work Experiences (years) } & $\leq 10$ & 232 & 35.0 \\
\hline & $11-20$ & 193 & 29.1 \\
\hline & $\geq 21$ & 238 & 35.9 \\
\hline \multirow[t]{3}{*}{ Monthly Income } & $\leq 2000$ & 219 & 33.0 \\
\hline & $2001-4000$ & 357 & 53.8 \\
\hline & $\geq 4001$ & 87 & 13.1 \\
\hline \multirow[t]{3}{*}{ Daily Work Hours } & $\leq 7 \mathrm{~h}$ & 55 & 8.3 \\
\hline & $8-10 h$ & 399 & 60.2 \\
\hline & $\geq 11 \mathrm{~h}$ & 209 & 31.5 \\
\hline \multirow[t]{3}{*}{ Connectedness in Advisory Networks } & Low & 74 & 11.2 \\
\hline & Middle & 467 & 70.4 \\
\hline & High & 122 & 18.4 \\
\hline \multirow[t]{3}{*}{ Connectedness in Friendship Networks } & Low & 109 & 16.4 \\
\hline & Middle & 466 & 70.3 \\
\hline & High & 88 & 13.3 \\
\hline \multirow[t]{3}{*}{ Emotional Exhaustion } & Low & 406 & 61.2 \\
\hline & Middle & 97 & 14.6 \\
\hline & High & 160 & 24.1 \\
\hline \multirow[t]{3}{*}{ Depersonalization } & Low & 510 & 76.9 \\
\hline & Middle & 49 & 7.4 \\
\hline & High & 104 & 15.7 \\
\hline \multirow[t]{3}{*}{ Lack of Personal Accomplishment } & Low & 328 & 49.5 \\
\hline & Middle & 105 & 15.8 \\
\hline & High & 230 & 34.7 \\
\hline
\end{tabular}

\section{Results}

\section{Sample characteristics}

Table 1 lists the characteristics of the sample population. Four types of PHC workers were included: doctors, nurses, public health workers, and village doctors. Nearly half of the respondents were village doctors (49.0\%), followed by doctors (19.8\%), nurses (15.8\%), and public health personnel (15.4\%). Females and males accounted for 44.5 and $55.5 \%$ of the respondents, respectively. Most participants were less than 46 years old $(65.5 \%)$ and had a college degree and below (81.3\%). Less than half of the rural PHC workers had fewer than 11 years of working 
experience $(35.0 \%)$. More than half of the participants earned 2001-4000 RMB every month (53.8\%) and worked $8-10 \mathrm{~h}$ every day $(60.2 \%)$.

\section{Connectedness in social networks and the job burnout situation of PHC workers}

Social networks included advisory and friendship networks. More than half of the participants were in the middle connectedness level in the advisory (70.4\%) and friendship (70.3\%) networks. In terms of job burnout, the emotional exhaustion (61.2\%) and depersonalization (76.9\%) of rural PHC workers were mainly in the low group. However, the low level of lack of personal accomplishment only accounted for $49.5 \%$ of respondents (Table 1).
Predictors affecting the influence of connectedness in social networks on job burnout among PHC workers A significant difference was found between the emotional exhaustion/depersonalization/lack of personal accomplishment levels on various control variables. The male respondents $\left(X^{2}=12.037, P=0.002\right)$ who had longer daily work hours $\left(\chi^{2}=14.163, P=0.007\right)$ seemed to have a high level of emotional exhaustion (Table 2). Rural PHC workers with a high level of educational background $\left(\chi^{2}=14.193, P=0.007\right)$ and had less work experiences $\left(\chi^{2}=17.9743, P=0.001\right)$ seemed to have a high level of depersonalization (Table 3). The lack of personal accomplishment of the different professional PHC workers varied $\left(\chi^{2}=15.391, P=0.017\right)$. Meanwhile, respondents with a high level of educational background $\left(X^{2}=13.429, P=0.009\right)$ and had less work experiences

Table 2 Correlations between emotional exhaustion level, and demographic, connectedness in networks of PHC workers

\begin{tabular}{|c|c|c|c|c|c|c|}
\hline \multirow[t]{2}{*}{ Characteristics } & & Low & Middle & High & $x^{2}$ & $P$ \\
\hline & & \multicolumn{5}{|l|}{$N(\%)$} \\
\hline \multirow[t]{4}{*}{ Types of work } & Doctors & $83(63.4)$ & $19(14.5)$ & $29(22.1)$ & 4.005 & 0.676 \\
\hline & Nurses & $60(57.1)$ & $19(18.1)$ & $26(24.8)$ & & \\
\hline & Public health workers & $69(67.6)$ & $13(12.7)$ & $20(19.6)$ & & \\
\hline & Village doctors & $194(59.7)$ & $46(14.2)$ & $85(26.2)$ & & \\
\hline \multirow[t]{2}{*}{ Gender } & Male & $230(62.5)$ & $39(10.6)$ & $99(26.9)$ & 12.037 & 0.002 \\
\hline & Female & $176(59.7)$ & $58(19.7)$ & $61(20.7)$ & & \\
\hline \multirow[t]{4}{*}{ Age } & $\leq 35$ & $99(54.4)$ & $30(16.5)$ & $53(29.1)$ & 7.516 & 0.276 \\
\hline & $36-45$ & $164(65.1)$ & $34(13.5)$ & $54(21.4)$ & & \\
\hline & $46-55$ & $97(61.8)$ & $26(16.6)$ & $34(21.7)$ & & \\
\hline & $\geq 56$ & $46(63.9)$ & $7(9.7)$ & $19(26.4)$ & & \\
\hline \multirow[t]{3}{*}{ Educational Background } & Undergraduate Degree and Above & $68(54.8)$ & $21(16.9)$ & $35(28.2)$ & 4.399 & 0.355 \\
\hline & College Degree & $204(63.4)$ & 49 (15.2) & $69(21.4)$ & & \\
\hline & High School and Below & $134(61.8)$ & $27(12.4)$ & $56(25.8)$ & & \\
\hline \multirow[t]{3}{*}{ Work Experiences (Years) } & $\leq 10$ & $129(55.6)$ & $40(17.2)$ & $63(27.2)$ & 5.107 & 0.276 \\
\hline & $11-20$ & $124(64.2)$ & $24(12.4)$ & $45(23.3)$ & & \\
\hline & $\geq 21$ & $153(64.3)$ & $33(13.9)$ & $52(21.8)$ & & \\
\hline \multirow[t]{3}{*}{ Monthly Income } & $\leq 2000$ & $127(58.0)$ & $37(16.9)$ & $55(25.1)$ & 3.496 & 0.478 \\
\hline & $2001-4000$ & $229(64.1)$ & $45(12.6)$ & $83(23.2)$ & & \\
\hline & $\geq 4001$ & $50(57.5)$ & $15(17.2)$ & $22(25.3)$ & & \\
\hline \multirow[t]{3}{*}{ Daily Work Hours } & $\leq 7 \mathrm{~h}$ & $42(76.4)$ & $8(14.5)$ & $5(9.1)$ & 14.163 & 0.007 \\
\hline & 8-10 h & $252(63.2)$ & $57(14.3)$ & $90(22.6)$ & & \\
\hline & $\geq 11 \mathrm{~h}$ & $112(53.6)$ & $32(15.3)$ & $65(31.1)$ & & \\
\hline \multirow[t]{3}{*}{ Connectedness in Advisory Networks } & Low & $45(60.8)$ & $4(5.4)$ & $25(33.8)$ & 9.469 & 0.050 \\
\hline & Middle & $289(61.9)$ & $73(15.6)$ & $105(22.5)$ & & \\
\hline & High & $72(59.0)$ & $20(16.4)$ & $30(24.6)$ & & \\
\hline \multirow[t]{3}{*}{ Connectedness in Friendship Networks } & Low & $65(59.6)$ & $5(4.6)$ & $39(35.8)$ & 18.613 & 0.001 \\
\hline & Middle & $281(60.3)$ & $81(17.4)$ & $104(22.3)$ & & \\
\hline & High & $60(68.2)$ & $11(12.5)$ & $17(19.3)$ & & \\
\hline
\end{tabular}


Table 3 Correlations between depersonalization level, and demographic, connectedness in networks of PHC workers

\begin{tabular}{|c|c|c|c|c|c|c|}
\hline \multirow[t]{2}{*}{ Characteristics } & & Low & Middle & High & $x^{2}$ & $P$ \\
\hline & & \multicolumn{5}{|l|}{$N(\%)$} \\
\hline \multirow[t]{4}{*}{ Types of work } & Doctors & $94(71.8)$ & $11(8.4)$ & $26(19.8)$ & 5.505 & 0.481 \\
\hline & Nurses & $81(77.1)$ & $7(6.7)$ & $17(16.2)$ & & \\
\hline & Public health workers & $86(84.3)$ & $6(5.9)$ & $10(9.8)$ & & \\
\hline & Village doctors & $249(76.6)$ & $25(7.7)$ & $51(15.7)$ & & \\
\hline \multirow[t]{2}{*}{ Gender } & Male & $285(77.4)$ & $22(6.0)$ & $61(16.6)$ & 2.679 & 0.262 \\
\hline & Female & $225(76.3)$ & $27(9.2)$ & $43(14.6)$ & & \\
\hline \multirow[t]{4}{*}{ Age } & $\leq 35$ & $128(70.3)$ & $16(8.8)$ & $38(20.9)$ & 6.769 & 0.343 \\
\hline & $36-45$ & $198(78.6)$ & $17(6.7)$ & $37(14.7)$ & & \\
\hline & $46-55$ & $126(80.3)$ & $11(7.0)$ & $20(12.7)$ & & \\
\hline & $\geq 56$ & $58(80.6)$ & $5(6.9)$ & $9(12.5)$ & & \\
\hline \multirow[t]{3}{*}{ Educational Background } & Undergraduate Degree and Above & $84(67.7)$ & $8(6.5)$ & $32(25.8)$ & 14.193 & 0.007 \\
\hline & College Degree & $252(78.3)$ & $29(9.0)$ & $41(12.7)$ & & \\
\hline & High School and Below & $174(80.2)$ & $12(5.5)$ & $31(14.3)$ & & \\
\hline \multirow[t]{3}{*}{ Work Experiences (Years) } & $\leq 10$ & $157(67.7)$ & $22(9.5)$ & $53(22.8)$ & 17.974 & 0.001 \\
\hline & $11-20$ & $158(81.9)$ & $11(5.7)$ & $24(12.4)$ & & \\
\hline & $\geq 21$ & $195(81.9)$ & $16(6.7)$ & $27(11.3)$ & & \\
\hline \multirow[t]{3}{*}{ Monthly Income } & $\leq 2000$ & $173(79.0)$ & $14(6.4)$ & $32(14.6)$ & 1.995 & 0.737 \\
\hline & $2001-4000$ & $274(76.8)$ & $26(7.3)$ & $57(16.0)$ & & \\
\hline & $\geq 4001$ & $63(72.4)$ & $9(10.3)$ & $15(17.2)$ & & \\
\hline \multirow[t]{3}{*}{ Daily Work Hours } & $\leq 7 \mathrm{~h}$ & $45(81.8)$ & $5(9.1)$ & $5(9.1)$ & 3.487 & 0.480 \\
\hline & $8-10 h$ & $311(77.9)$ & $27(6.8)$ & $61(15.3)$ & & \\
\hline & $\geq 11 \mathrm{~h}$ & $154(73.7)$ & $17(8.1)$ & $38(18.2)$ & & \\
\hline \multirow[t]{3}{*}{ Connectedness in Advisory Networks } & Low & $53(71.6)$ & $1(1.4)$ & $20(27.0)$ & 18.020 & 0.001 \\
\hline & Middle & $352(75.4)$ & $43(9.2)$ & $72(15.4)$ & & \\
\hline & High & $105(86.1)$ & $5(4.1)$ & $12(9.8)$ & & \\
\hline \multirow[t]{3}{*}{ Connectedness in Friendship Networks } & Low & $77(70.6)$ & $5(4.6)$ & $27(24.8)$ & 9.955 & 0.041 \\
\hline & Middle & $361(77.5)$ & $39(8.4)$ & $66(14.2)$ & & \\
\hline & High & $72(81.8)$ & $5(5.7)$ & $11(12.5)$ & & \\
\hline
\end{tabular}

$\left(\chi^{2}=15.614, P=0.004\right)$ seemed to have a high level of lack of personal accomplishment (Table 4).

After discovering that gender and daily work hours were significantly associated with emotional exhaustion, educational background and work experiences were revealed to be significantly associated with depersonalization and lack of personal accomplishment. Moreover, the type of work was significantly associated with the lack of personal accomplishment. These factors were controlled using cumulative logistic regression analysis to examine the impact of connectedness in social networks on the workers' job burnout.

As shown in Table 5, connectedness level in friendship networks had a significant impact on emotional exhaustion. Compared with PHC workers who had a high level of connectedness in friendship networks, participants with a low level of connectedness in friendship networks seemed to have an increased degree of emotional exhaustion $(\beta=0.769,95 \% C I=0.080-1.458, P=0.029)$. Table 6 indicates that the connectedness degree in advisory networks had a significant impact on depersonalization. The respondents in the middle level of connectedness in advisory networks had a higher level of depersonalization than a high level of connectedness $(\beta=0.739,95 \% C I=0.130-1.348, P=0.017)$. Table 7 reveals that the connectedness degree in social networks had a significant impact on the workers' lack of personal accomplishment. Respondents in the low $(\beta=1.042,95 \%$ $C I=0.309-1.775, P=0.005)$ and middle $(\beta=0.583,95 \%$ $C I=0.111-1.055, P=0.015)$ levels of connectedness in their advisory networks had a higher level of lack of accomplishment than a high level of connectedness. 
Table 4 Correlations between lack of personal accomplishment level, and demographic, connectedness in networks of PHC workers

\begin{tabular}{|c|c|c|c|c|c|c|}
\hline \multirow[t]{2}{*}{ Characteristics } & & Low & Middle & High & $x^{2}$ & $P$ \\
\hline & & \multicolumn{5}{|l|}{$N(\%)$} \\
\hline \multirow[t]{4}{*}{ Types of work } & Doctors & $54(41.2)$ & $17(13.0)$ & $60(45.8)$ & 15.391 & 0.017 \\
\hline & Nurses & $50(47.6)$ & $13(12.4)$ & $42(40.0)$ & & \\
\hline & Public health workers & $48(47.1)$ & $22(21.6)$ & $32(31.4)$ & & \\
\hline & Village doctors & $176(54.2)$ & $53(16.3)$ & $96(29.5)$ & & \\
\hline \multirow[t]{2}{*}{ Gender } & Male & $183(49.7)$ & $58(15.8)$ & $127(34.5)$ & 0.022 & 0.989 \\
\hline & Female & $145(49.2)$ & $47(15.9)$ & $103(34.9)$ & & \\
\hline \multirow[t]{4}{*}{ Age } & $\leq 35$ & $76(41.8)$ & $33(18.1)$ & $73(40.1)$ & 7.635 & 0.266 \\
\hline & $36-45$ & $134(53.2)$ & $39(15.5)$ & $79(31.3)$ & & \\
\hline & $46-55$ & $81(51.6)$ & $20(12.7)$ & $56(35.7)$ & & \\
\hline & $\geq 56$ & $37(51.4)$ & $13(18.1)$ & $22(30.6)$ & & \\
\hline \multirow[t]{3}{*}{ Educational Background } & Undergraduate Degree and Above & $48(38.7)$ & $17(13.7)$ & $59(47.6)$ & 13.426 & 0.009 \\
\hline & College Degree & $159(49.4)$ & $55(17.1)$ & $108(33.5)$ & & \\
\hline & High School and Below & $121(55.8)$ & $33(15.2)$ & $63(29.0)$ & & \\
\hline \multirow[t]{3}{*}{ Work Experiences (Years) } & $\leq 10$ & $93(40.1)$ & $43(18.5)$ & $96(41.4)$ & 15.614 & 0.004 \\
\hline & $11-20$ & $97(50.3)$ & $28(14.5)$ & $68(35.2)$ & & \\
\hline & $\geq 21$ & $138(58.0)$ & $34(14.3)$ & $66(27.7)$ & & \\
\hline \multirow[t]{3}{*}{ Monthly Income } & $\leq 2000$ & $120(54.8)$ & $34(15.5)$ & $65(29.7)$ & 4.717 & 0.318 \\
\hline & $2001-4000$ & $169(47.3)$ & $58(16.2)$ & $130(36.4)$ & & \\
\hline & $\geq 4001$ & $39(44.8)$ & $13(14.9)$ & $35(40.2)$ & & \\
\hline \multirow[t]{3}{*}{ Daily Work Hours } & $\leq 7 \mathrm{~h}$ & $25(45.5)$ & $10(18.2)$ & $20(36.4)$ & 0.866 & 0.929 \\
\hline & $8-10 h$ & $202(50.6)$ & $60(15.0)$ & $137(34.3)$ & & \\
\hline & $\geq 11 \mathrm{~h}$ & $101(48.3)$ & $35(16.7)$ & $73(34.9)$ & & \\
\hline \multirow[t]{3}{*}{ Connectedness in Advisory Networks } & Low & $26(35.1)$ & $9(12.2)$ & $39(52.7)$ & 22.744 & 0.000 \\
\hline & Middle & $232(49.7)$ & $69(14.8)$ & $166(35.5)$ & & \\
\hline & High & $70(57.4)$ & $27(22.1)$ & $25(20.5)$ & & \\
\hline \multirow[t]{3}{*}{ Connectedness in Friendship Networks } & Low & $43(39.4)$ & $16(14.7)$ & $50(45.9)$ & 12.030 & 0.017 \\
\hline & Middle & $232(49.8)$ & $74(15.9)$ & $160(34.3)$ & & \\
\hline & High & $53(60.2)$ & $15(17.0)$ & $20(22.7)$ & & \\
\hline
\end{tabular}

Table 5 Outcome of a cumulative logistic regression model examining control variables, connectedness in networks with emotional exhaustion

\begin{tabular}{|c|c|c|c|c|c|c|c|}
\hline \multirow[t]{2}{*}{ Characteristics } & & \multirow[t]{2}{*}{ Reference } & \multirow[t]{2}{*}{$B$} & \multirow[t]{2}{*}{$P$} & \multirow[t]{2}{*}{ OR } & \multicolumn{2}{|l|}{$95 \% \mathrm{Cl}$} \\
\hline & & & & & & Lower & Upper \\
\hline \multirow[t]{5}{*}{ Control Variables } & Gender & & & & & & \\
\hline & Male & Female & -0.053 & 0.742 & 0.948 & -0.369 & 0.263 \\
\hline & \multicolumn{7}{|c|}{ Daily Work Hours } \\
\hline & $\leq 7 \mathrm{~h}$ & $\geq 11 \mathrm{~h}$ & -1.165 & 0.001 & 0.312 & -1.856 & -0.475 \\
\hline & $8-10 h$ & & -0.484 & 0.005 & 0.616 & -0.822 & -0.145 \\
\hline \multirow[t]{2}{*}{ Connectedness in Advisory Networks } & Low & High & -0.382 & 0.283 & 0.682 & -1.081 & 0.316 \\
\hline & Middle & & -0.401 & 0.081 & 0.669 & -0.851 & 0.050 \\
\hline \multirow[t]{2}{*}{ Connectedness in Friendship Networks } & Low & High & 0.769 & 0.029 & 2.157 & 0.080 & 1.458 \\
\hline & Middle & & 0.399 & 0.137 & 1.490 & -0.127 & 0.925 \\
\hline
\end{tabular}


Table 6 Outcome of a cumulative logistic regression model examining control variables, connectedness in networks with depersonalization

\begin{tabular}{|c|c|c|c|c|c|c|c|}
\hline \multirow[t]{2}{*}{ Characteristics } & & \multirow[t]{2}{*}{ Reference } & \multirow[t]{2}{*}{$B$} & \multirow[t]{2}{*}{$P$} & \multirow[t]{2}{*}{ OR } & \multicolumn{2}{|l|}{$95 \% \mathrm{Cl}$} \\
\hline & & & & & & Lower & Upper \\
\hline \multirow[t]{6}{*}{ Control Variables } & Educational Background & & & & & & \\
\hline & Undergraduate Degree and Above & High School and Below & 0.439 & 0.107 & 1.551 & -0.094 & 0.072 \\
\hline & College Degree & & -0.088 & 0.699 & 0.915 & -0.536 & 0.359 \\
\hline & Work Experiences (Years) & & & & & & \\
\hline & $\leq 10$ & $\geq 21$ & 0.794 & 0.001 & 2.212 & 0.337 & 1.251 \\
\hline & $11-20$ & & 0.021 & 0.934 & 1.021 & -0.484 & 0.527 \\
\hline \multirow[t]{2}{*}{ Connectedness in Advisory Networks } & Low & High & 0.579 & 0.194 & 1.784 & -0.294 & 1.453 \\
\hline & Middle & & 0.739 & 0.017 & 2.093 & 0.130 & 1.348 \\
\hline \multirow[t]{2}{*}{ Connectedness in Friendship Networks } & Low & High & 0.206 & 0.619 & 1.228 & -0.606 & 1.018 \\
\hline & Middle & & -0.090 & 0.784 & 0.914 & -0.733 & 0.552 \\
\hline
\end{tabular}

Otherwise, the results showed that doctors $(\beta=0.748$, 95\% $C I=0.304-1.192, \quad P=0.001)$ and public health workers $(\beta=0.523,95 \% C I=0.017-1.029, P=0.043)$ in township hospitals had a higher level of lack of personal accomplishment than village doctors.

\section{Discussion}

This study demonstrated that 24.1, 15.7, and $34.7 \%$ of PHC workers in rural China had high levels of emotional exhaustion, depersonalization, and lack of personal accomplishment, respectively. Overall, serious job burnout of rural PHC workers in China still exists. These findings are similar with the conclusions reported in previous studies about the burnout symptom of PHC workers
[8]. With the implementation of the national health coverage strategy, the workload of PHC workers in China is gradually increasing. Specifically, only $8.3 \%$ PHC workers had reasonable working times of less than $8 \mathrm{~h}$ a day. Respondents who had longer daily work hours reported high levels of emotional exhaustion. Meanwhile, rural PHC workers who had less work experiences experienced high levels of depersonalization and lack of personal accomplishment. On the one hand, physicians with few work years had a high level of lack of personal accomplishment due to the lack of respect from patients [26]. On the other hand, PHC workers with less work experiences had more single content health services compared with workers who had longer work years, so

Table 7 Outcome of a cumulative logistic regression model examining control variables, connectedness in networks with lack of personal accomplishment

\begin{tabular}{|c|c|c|c|c|c|c|c|}
\hline \multirow[t]{2}{*}{ Characteristics } & & \multirow[t]{2}{*}{ Reference } & \multirow[t]{2}{*}{$B$} & \multirow[t]{2}{*}{$P$} & \multirow[t]{2}{*}{$O R$} & \multicolumn{2}{|l|}{$95 \% \mathrm{Cl}$} \\
\hline & & & & & & Lower & Upper \\
\hline \multirow[t]{10}{*}{ Control Variables } & Types of work & & & & & & \\
\hline & Doctors & Village Doctors & 0.748 & 0.001 & 2.112 & 0.304 & 1.192 \\
\hline & Nurses & & 0.365 & 0.107 & 1.440 & -0.079 & 0.809 \\
\hline & Public Health Workers & & 0.523 & 0.043 & 1.687 & 0.017 & 1.029 \\
\hline & Educational Background & & & & & & \\
\hline & Undergraduate Degree and Above & High School and Below & 0.214 & 0.376 & 1.238 & -0.260 & 0.688 \\
\hline & College Degree & & -0.036 & 0.845 & 0.964 & -0.395 & 0.323 \\
\hline & Work Experiences (Years) & & & & & & \\
\hline & $\leq 10$ & $\geq 21$ & 0.446 & 0.022 & 1.562 & 0.063 & 0.829 \\
\hline & $11-20$ & & 0.217 & 0.268 & 1.242 & -0.167 & 0.600 \\
\hline \multirow[t]{2}{*}{ Connectedness in Advisory Networks } & Low & High & 1.042 & 0.005 & 2.834 & 0.309 & 1.775 \\
\hline & Middle & & 0.583 & 0.015 & 1.791 & 0.111 & 1.055 \\
\hline \multirow[t]{2}{*}{ Connectedness in Friendship Networks } & Low & High & 0.607 & 0.074 & 1.834 & -0.060 & 1.273 \\
\hline & Middle & & 0.375 & 0.145 & 1.454 & -0.129 & 0.879 \\
\hline
\end{tabular}


they had a high level of depersonalization. In addition, compared with village doctors, physicians and public health workers in township hospitals had higher levels of lack of personal accomplishment. These results can be related to the relationship between the different types of PHC workers and service objects. The relationship between village doctors and residents was closer and the influence among residents was stronger compared with the workers in township hospitals. Hence, village doctors seemed to have a high level of personal accomplishment. At the same time, this outcome also showed the important influence of interpersonal relationship on job burnout.

The majority of PHC workers involved in the social networks in rural China were in the high and middle levels of connectedness. Thus, the connection and cooperation among different types of PHC professionals was gradually strengthening through the implementation of a team model to provide health services. Compared with the previous independent health service delivery model, the team model promotes the integration of medical intervention and prevention and strengthens the establishment of the three-tiered rural health network in China [27]. However, 11.2 and $16.4 \%$ of the PHC workers were still in the low level of connectedness in advisory networks and friendship networks, respectively. The environment of inadequate PHC workers required us to pay attention to each PHC worker. Meanwhile, this research showed that the connectedness of PHC workers involved in social networks could affect their job burnout. Therefore, through the analysis of the relationship between the two types of connectedness in social network and the three dimensions of job burnout, this work could provide some suggestions to alleviate the problem of job burnout of PHC workers.

Results of the cumulative regression model revealed that an individual with a low level of connectedness in friendship networks had serious emotional exhaustion. Two reasons were found for such an outcome. First, personal friendship can help complete the job and reduce the pressure on PHC workers, especially in rural China. In terms of physicians, one chief of public health said: "Some doctors were reluctant to do public health works because of their heavy workload. So I could only convince him through the identity of a friend, not force him to do it." As for public health workers, some public health tasks (such as conducting health follow-up) are completed because of the friendship with village doctors resulting from the close connections between such doctors and residents [28]. Therefore, the pressure of completing work and the emotional exhaustion of PHC workers can be relieved through the establishment of friendships with other employees. Second, the establishment of friendship networks can help PHC workers have a homogeneous working atmosphere and environment so as to reduce emotional exhaustion. The previous study showed that a high degree of connectedness involving friendship networks enhances the dissemination of knowledge, imitation of behaviors, and related social processes, thereby resulting in the homogeneity of the cultural atmosphere and practice patterns [18]. Moreover, in a relatively relaxed working environment, PHC workers can talk about their work problems and improve their abilities with help from colleagues, hence they have low level of emotional exhaustion. Therefore, a high connectedness level of rural PHC workers in friendship networks could mitigate the emotional exhaustion of working, thus supporting the results of this study. However, informal communication paths (friendship) can be difficult to supervise and manage within organizations. Hence, leaders should pay attention to the correct guidance of communication behavior.

In addition, the research findings indicated that PHC workers with a low level of connectedness in advisory networks seemed to have a high level of depersonalization and lack of personal accomplishment. Depersonalization means feelings of callousness in treating colleagues or service objects [29]. Hence, such individuals do not exhibit enthusiasm about anything. From the perspective of social capital, a person with social relationships can acquire knowledge and information, and such capability can be translated into the individual's abilities [30]. Therefore, a high connectedness level in advisory networks means that individuals have strong working abilities. People with competence usually have a positive attitude toward the job according to the "knowledge-attitude-practice" model [31]. It was logical that PHC workers who had a high level of connectedness involved in advisory networks also had a high degree of working abilities, a positive attitude, and a low level of depersonalization. Meanwhile, PHC workers with a high level of connectedness involved in advisory networks were prone to have personal accomplishments. A previous research posited that individuals with high connectedness reflected a high degree of individual prestige and influence ability among colleagues [32]. PHC workers have psychological needs for social respect. This can explain the previous conclusion that the level of lack of personal accomplishment of village doctors was lower than that of doctors and public health workers in township hospitals because the former had more individual prestige and influence ability among residents compared with their counterparts in townships. Furthermore, PHC workers with a high level of connectedness are located at the center of advisory networks; hence, their behaviors and ideas could have a strong influence on others, even in 
organizations. The level of burnout is no exception. Managers of rural health institutions should consider individuals with a high level of connectedness in advisory networks as core staff of the team [33] and establish an incentive mechanism for these core members. Core workers with lower burnout level in the organizations can influence and even reduce the overall burnout level of PHC workers.

This study had several limitations. First, these samples might not represent the conditions of all rural PHC workers because the convenience sampling method was used. Second, this research analyzed that social network affected the job burnout of PHC workers in rural China but only through using the degree centrality index. Indexes could reflect the structural characteristics of social networks, which may also influence the job burnout level of rural PHC workers. Third, this study took the connectedness of PHC workers in their advisory and friendship networks into consideration, while it ignored family network. Thus, further works must be conducted to expand the knowledge in this area.

\section{Conclusions}

PHC workers in rural China face a severe problem of job burnout. The workers' level of emotional exhaustion was affected by the daily working hours beyond the reasonable range. The problem of depersonalization and lack of personal accomplishment of less experienced personnel, doctors, and public health workers in township hospitals should be addressed further in the future. Meanwhile, individuals with a low level of connectedness in friendship networks had serious emotional exhaustion, thereby indicating the importance of establishing and strengthening organizational culture. Organizations should pay more attention to informal communication networks among staff, establish an informal communication platform and information feedback mechanism, promote and manage friendship networks, and help PHC workers relieve the problem of emotional exhaustion. Meanwhile, PHC workers with low connectedness level of advisory networks had a high level of depersonalization and lack of personal accomplishment. Thus, managers should advance the core position of individuals with a high level of connectedness in advisory networks and have them play the role of "opinion leader" so that they can help others overcome burnout symptoms.

\section{Supplementary information}

Supplementary information accompanies this paper at https://doi.org/10. 1186/s12913-020-05426-9.

Additional file 1. Questionnaire on Social Network and Job Burnout of Primary Health Care Workers in Rural

\section{Abbreviations}

PHC: Primary Health Care; N: Number; P: P-Value; B: Beta; OR: Odds Ratio; $\mathrm{Cl}$ : Confidence Interval

\section{Acknowledgements}

The authors thank the Health Care Commission in Zhijiang, Zaoyang, and Suizhou counties in Hubei province, and Tanghe, Xixian, and Huaibin counties in Henan province, for their willingness to support this survey.

\section{Authors' contributions}

YQM, HF and ZCF contributed to the conception and design of the project; YQM contributed to the analysis and interpretation of the data; HF, DF, XYC, $J Y$ and YQL contributed to the data acquisition and provided statistical analysis support; YQM drafted the article. All authors supplied critical revisions to the manuscript and gave final approval of the version to be published.

\section{Funding}

National Natural Science Foundation of China (grant no. 71673098) funded this research.

\section{Availability of data and materials}

The datasets used and/or analyzed during the current study are available from the corresponding author on reasonable request. Contact information: zcfeng@hust.edu.cn.

\section{Ethics approval and consent to participate}

The approval for this study was obtained from the Ethics Committee of Tongji Medical College, Huazhong University of Science and Technology (IORG No: IORG0003571). Written consents were obtained from the participants at the beginning of the interview. Participants were fully informed before providing written consent to take part in the study.

Consent for publication

Not applicable.

\section{Competing interests}

The authors declare no conflict of interest.

\section{Author details}

${ }^{1}$ School of Medicine and Health Management, Tongji Medical College, Huazhong University of Science and Technology, Wuhan 430030, Hubei, China. ${ }^{2}$ Research center for Rural Health Services, Hubei Province Key Research Institute of Humanities and Social Sciences, Wuhan 430030, Hubei, China. ${ }^{3}$ The First Affiliated Hospital of Zhengzhou University, Zhengzhou 450052, China. ${ }^{4}$ School of Pharmacy, Tongji Medical College, Huazhong University of Science and Technology, Wuhan 430030, Hubei, China.

Received: 19 August 2019 Accepted: 12 June 2020

Published online: 18 June 2020

\section{References}

1. Litsios S. On the world health organization's neglect of the role of medical doctors in its conception and practice of primary health care. Int J Health Serv. 2019;49:642-57.

2. Saijo Y, Yoshioka E, Hanley SJB, Kitaoka K, Yoshida T. Job stress factors affect workplace resignation and burnout among Japanese rural physicians. Tohoku J Exp Med. 2018;245:167-77. https://doi.org/10.1620/tjem.245.167.

3. Ma X. Report of the state council on the management of the medical staff and the implementation of the law on licensed physicians. Beiling: Tenth Meeting of the Standing Committee of the Thirteenth National People's Congress; 2019.

4. Zhu A, Tang S, Thu NTH, Supheap L, Liu X. Analysis of strategies to attract and retain rural health workers in Cambodia, China, and Vietnam and context influencing their outcomes. Hum Resors Health. 2019;17. https://doi. org/10.1186/s12960-018-0340-6.

5. Selamu M, Thornicroft G, Fekadu A, Hanlon C. Conceptualisation of jobrelated wellbeing, stress and burnout among healthcare workers in rural Ethiopia: a qualitative study. BMC Health Serv Res. 2017;17. https:/doi.org/ 10.1186/s12913-017-2370-5. 
6. Schwarzer R, Hallum S. Perceived teacher self-efficacy as a predictor of job stress and burnout: mediation analyses. Appl Psychol. 2008:57:152-71. https://doi.org/10.1111/j.1464-0597.2008.00359.x.

7. West CP, Dyrbye LN, Shanafelt TD. Physician burnout: contributors, consequences and solutions. J Intern Med. 2018;283:516-29. https://doi.org/ 10.1111/joim. 12752.

8. Xu W, Pan Z, Li Z, Lu S, Zhang L. Job burnout among primary healthcare workers in rural China: a multilevel analysis. Int J Env Res Pub He. 2020;17: 727. https://doi.org/10.3390/ijerph17030727.

9. Liebenberg AR, Coetzee Jr JF, Conradie HH, Coetzee JF. Burnout among rural hospital doctors in the Western cape: comparison with previous south African studies. Afr J Prim Health Care Fam Med 2018;10: e1-e7. doi:https:// doi.org/10.4102/phcfm.v10i1.1568.

10. Hu H, Liu L, Zhao F, Yao Y, Gao Y, Wang G. Factors related to job burnout among community nurses in Changchun, China. J Nurs Res. 2015;23:172-80. https://doi.org/10.1097/jnr.0000000000000072.

11. Sagar Dugani HALR, Jeremy Veillard GMGL. Prevalence and factors associated with burnout among frontline primary health care providers in low- and middle-income countries: A systematic review. Gates Open Res. 2019;2:1-29. https://doi.org/10.12688/gatesopenres.12779.3.

12. Szafran O, Kennett SL, Bell NR, Torti JMI. Interprofessional collaboration in diabetes care: perceptions of family physicians practicing in or not in a primary health care team. BMC Fam Pract. 2019;20. https://doi.org/10.1186/ s12875-019-0932-9.

13. Hayes B, Bonnet A. Job satisfaction, stress and burnout associated with haemodialysis nursing: a review of literature. J Renal Care. 2010;36:174-9. https://doi.org/10.1111/j.1755-6686.2010.00194.x.

14. Sun J, Bai H, Li J, Lin P, Zhang H, Cao F. Predictors of occupational burnout among nurses: a dominance analysis of job stressors. J Clin Nurs. 2017;26: 4286-92. https://doi.org/10.1111/jocn.13754.

15. Son S, Kim D, Kim M. How perceived interpersonal justice relates to job burnout and intention to leave: the role of leader-member exchange and cognition-based trust in leaders. Asian J Soc Psychol. 2014;17:12-24. https:// doi.org/10.1111/ajsp.12038.

16. García-Izquierdo M, Ríos-Rísquez MI. The relationship between psychosocial job stress and burnout in emergency departments: an exploratory study. Nurs Outlook. 2012;60:322-9. https://doi.org/10.1016/j. outlook.2012.02.002

17. Singh P, Suar D, Leiter MP. Antecedents, work-related consequences, and buffers of job burnout among Indian software developers. J Leadersh Org Stud. 2011;19:83-104. https://doi.org/10.1177/1548051811429572.

18. Wensing MJP, Eijk MVD, Koetsenruijter J, Bloem BR, Munneke M, Faber MJ. Connectedness of healthcare professionals involved in the treatment of patients with Parkinson's disease: a social networks study. Implement Sci. 2011;6:67. https://doi.org/10.1186/1748-5908-6-67.

19. Shaukat R, Yousaf A, Sanders K. Examining the linkages between relationship conflict, performance and turnover intentions role of job burnout as a mediator. Int J Confl Manag. 2017;28:4-23.

20. Reyes Ortega MA, Kuczynski AM, Kanter JW, de Montis IA, Santos MM. A preliminary test of a social connectedness burnout intervention for Mexican mental health professionals. Psychol Rec. 2019;69:267-76. https://doi.org/10. 1007/s40732-019-00338-5.

21. Keating NL, Ayanian JZ, Cleary PD, Marsden PV. Factors affecting influential discussions among physicians: a social network analysis of a primary care practice. J Gen Intern Med. 2007;22:794-8. https://doi.org/10.1007/s11606007-0190-8.

22. Kilduff M, Tsai W. Social networks and organizations. London: SAGE; 2003.

23. Van Beek AP, Wagner C, Spreeuwenberg PP, Frijters DH, Ribbe MW, Groenewegen PP. Communication, advice exchange and job satisfaction of nursing staff: a social network analyses of 35 long-term care units. BMC Health Serv Res. 2011;11:140. https://doi.org/10.1186/1472-6963-11-140.

24. Schaufeli WB, Bakker AB. Job demands, job resources, and their relationship with burnout and engagement: a multi-sample study. J Organ Behav. 2004; 25:293-315. https://doi.org/10.1002/job.248.

25. Liu L. Social network, centrality and job performance in organizations (in chinese): Zhongshan university press; 2008.

26. Wang Z, Xie Z, Dai J, Zhang L, Huang Y, Chen B. Physician burnout and its associated factors: a cross-sectional study in Shanghai. J Occup Health. 2014;56:73-83.

27. Meng Q, Mills A, Wang L, Han Q. What can we learn from China's health system reform? BMJ. 2019:12349. https://doi.org/10.1136/bmj.12349.
28. Zhou H, Zhang W, Zhang S, Wang F, Zhong Y, Gu L, et al. Health providers' perspectives on delivering public health services under the contract service policy in rural China: evidence from Xinjian County. BMC Health Serv Res. 2015;15. https://doi.org/10.1186/s12913-015-0739-x.

29. Miranda-Ackerman RC, Barbosa-Camacho FJ, Sander-Möller MJ, BuenrostroJiménez $A D$, Mares-País $R$, Cortes-Flores $A O$, et al. Burnout syndrome prevalence during internship in public and private hospitals: a survey study in Mexico. Med Educ Online. 2019;24:1593785. https://doi.org/10.1080/ 10872981.2019.1593785.

30. Paul SA, Seok-Woo K. Social capital: prospects for a new concept. Acad Manag Rev. 2002;27:17-40

31. Herzog R, Alvarez-Pasquin MJ, Diaz C, Del BJ, Estrada JM, Gil A. Are healthcare workers' intentions to vaccinate related to their knowledge, beliefs and attitudes? A systematic review. BMC Public Health. 2013;13:154. https://doi.org/10.1186/1471-2458-13-154.

32. Han J, Van Dongen K. Friendship network centrality and the performance of soccer players: the role of cognitive accuracy. Hum Perform. 2015;28:265-79. https://doi.org/10.1080/08959285.2015.1021044.

33. Dreison KC, White DA, Bauer SM, Salyers MP, McGuire AB. Integrating selfdetermination and job demands-resources theory in predicting mental health provider burnout. Adm Policy Ment Hlth. 2018:45:121-30. https://doi. org/10.1007/s10488-016-0772-z.

\section{Publisher's Note}

Springer Nature remains neutral with regard to jurisdictional claims in published maps and institutional affiliations.

\section{Ready to submit your research? Choose BMC and benefit from:}

- fast, convenient online submission

- thorough peer review by experienced researchers in your field

- rapid publication on acceptance

- support for research data, including large and complex data types

- gold Open Access which fosters wider collaboration and increased citations

- maximum visibility for your research: over $100 \mathrm{M}$ website views per year

At BMC, research is always in progress.

Learn more biomedcentral.com/submissions 